\title{
Lexical Density in UU Cipta Kerja: A Case Study of Controversial Articles
}

\author{
Marlia $^{1, *}$ Iwa Lukmana ${ }^{1}$ Wawan Gunawan ${ }^{1}$ \\ ${ }^{1}$ Linguistics Study Program, Universitas Pendidikan Indonesia, Bandung, Indonesia \\ *Corresponding author. Email: marlia@unpas.ac.id
}

\begin{abstract}
This research describes the lexical density in the controversial articles from the UU Cipta Kerja. This study used a qualitative approach by adopting the notion of Halliday's lexical density method. The results of the analysis show that controversial articles which are contained in Chapter IV concerning Employment in the UU Cipta Kerja have a very high lexical density index, namely 10,81. The high lexical density index contained in these articles indicates the high formality of the text so that there is a tendency for readers to be difficult to understand, especially for the laypeople. Therefore, it is necessary to simplify the legal language to improve the reader's understanding in order to realize obedience and legal order as a whole.
\end{abstract}

Keywords: lexical density, controversial articles, UU Cipta Kerja.

\section{INTRODUCTION}

Laypeople difficult to understand legal language. There is a tendency due to the complexity of the language used [1]; [2]; [14]; [22];[23]. Susette said that "Legal writing is further complicated by: ultra-long sentences, complex language constructions, massive amounts of content, needed or not" [17]. John added that "Legal writing is one of the most complicated and ambiguous languages for the common person to understand" [10].

The complexity of a text can be known through lexical density analysis. Lexical density is a formula that can be used to analyze a text. In addition, lexical density is a measure to compare the number of content words and function words in a text [20]. Lexical density is linguistically related to word content. As it is known that according to its function, vocabulary can be categorized into content words and function words. The content word has meaning and referent, while the function word has a function in the formation of grammar [13]. Lexical density can be seen from the proportion of lexical words to the whole discourse. Thus, the lexical density can be found by calculating the ratio between the lexical word and the number of clauses [4]. In addition, the lexical density in question is dense in information and lexical words. Information is compressed through simplex clauses and nominalization. On the side of the simplex clause, the compressed information can be in the form of an embedding clause, a prepositional phrase, or on the subject/complementary element. On the nominalization side, information compaction occurs at the lexis level. Nominalization is an attempt to distinguish from, for example, process (verb), condition (adjective), circumstance (adverb), and logic (conjunction). Condensation of information through nominalization is often an incongruent lexis disclosure involving grammatical metaphors [24].

The high lexical density in legal texts does not necessarily indicate the reader's understanding. It is proven by the fact that there are still many the laypeople who cannot understand the legal language easily.

Several studies show that the use of Indonesian in the legal document still needs to be improved. Many foreign terms, especially Dutch and English, whose meanings are poorly understood and inconsistent, have inaccurate diction, long and convoluted sentences [11]. Most Indonesians feel that the legal language in Indonesia is confusing and too difficult to understand. Legal language is considered inflexible, rigid, the sentences are too long so that the reader has to repeat several times to find out what it means [8]. Problems that arise in legal language, among others, are caused by legal experts formulating or describing something in long sentences with many clauses, using special terms without explanation, using double or vague terms, using foreign terms, reluctant to shift from the format that has been established exists [7]. This is certainly an 
indication that the legal language is so complex that it is difficult to understand, especially for the laypeople.

Several studies related to lexical density show that the lexical density of a material/reading (in this case, the local content textbook of the Madurese language for grade VI SD) can affect the reader (student) in understanding the reading material. If the material is grammatically configured, allow the text to be less difficult to understand. Meanwhile, if the text contains many lexical items, then the text can be categorized as difficult text. The number of lexical items in a text can indicate the level of difficulty of the text. The more lexical items, the more difficult the text to understand. [13]. Syarif found that the level of lexical density decreased due to the number of complex clauses used. In addition, the results of data analysis also show that there is a significant relationship between lexical density and grammatical complexity [18]. Furthermore, Ramadhan shows that the level of lexical density in written texts tends to be high while the level of grammatical complexity in written texts tends to be low. Therefore, written text contains more information because of the high number of lexical items as a comparison of the total number of words and uses simple grammar because of the low number of clauses per sentence. Spoken texts contain less information due to the low number of lexical items (lexical items) in comparison to the total number of words and use complicated grammar due to the high number of clauses per sentence [16]. Putra and Lukmana showed that all the textbooks studied had consistent lexical density, lexical variation, and grammatical complexity from one grade level to another [15].

The findings from previous studies generally show that legal language is complex and difficult to understand, but the study has not shown the level of complexity from the lexical density perspective. The study is more focused on the use of diction and sentences used without measuring the level of lexical density so that they tend to be less valid. Similarly, previous research findings related to lexical density, generally only analyze the lexical density of textbooks/teaching materials, not yet analyze lexical density in legal documents.

Thus, in this study, we will try to examine the lexical density in legal documents, in this case the UU Cipta Kerja which had become a controversial law, especially among workers. Lexical density is used to find the level of lexical density so that it can show how high the complexity of the language contained in legal documents is. Through this study, it is hoped that it can become input, especially for policymakers in legal documents.

\section{Lexical Density}

According to Johansson the term lexical density is used in text analysis to describe the proportion of lexical elements or content word (nouns, verbs, adjectives, and adverbs) to the total number of words [9]. Halliday asserts that lexical density is a measure of the density of information in each part of the text, based on how tightly the lexical elements (content words) have been packed into the grammatical structure [4]. Thornbury and Slade add that lexical density is a measure of the ratio of the content words of the text to its function words [20].

In line with the opinion above, Wiratno explains that texts that have lexical density contain more lexical words or content words (nouns, verb-predicators, adjectives, and certain adverbs) rather than structural words (conjunctions, articles, prepositions, etc.) [24].

"To measure lexical density, simply divide the number of lexical items by the number of ranking clauses" [5]. Thus, to calculate the lexical density proposed by Halliday, it can be described as follows.

\section{Lexical Density $=\underline{\text { number of lexical items }}$ numbers of ranking clauses}

The lexical density of a text can be found by counting the number of content words in the text as a proportion of all the words in the text. Content words consist of nouns, verbs, adverbs and adjectives. Meanwhile, non-content words consist of prepositions, conjunctions, auxiliary verbs and pronouns [3].

The formula proposed by Halliday related to lexical density in this study will be used to calculate the lexical density contained in legal language and legal language after the implementation of plain language.

\section{METHOD}

This research examines the use of language in the context of legal texts. By considering the context, the researchers used a qualitative approach. The reason for using a qualitative approach is that the data in this study is loaded with the realization of the meaning of legal clauses. The interpretation of the realization of the meaning in the form of clauses in the legal document (UU Cipta Kerja) requires a close interpretation so as not to cause ambiguity for the readers. In order not to deviate from the essence of this research, the researcher will describe the legal document (UU Cipta Kerja) using the idea of lexical density so that the linguistic evidence obtained becomes meaningful in the development of legal language.

The data in this study is UU Cipta Kerja, which consists of 15 chapters and 186 articles. It regulates 
employment to the environment. There are several articles that are considered problematic and controversial in Chapter IV concerning Manpower of the UU Cipta Kerja, namely Article 59 concerning contract workers, Article 77 concerning working hours, Article 78 concerning overtime provisions, Article 79 concerning leave and rest rights [19]. Thus, the primary data in this study will also be focused on these controversial articles.

The text of the UU Cipta Kerja is obtained by downloading it on a trusted page, namely https://jdih.setneg.go.id/Produk. The data that has been obtained will be analyzed in the following order: (1) identify lexical words/content words; (2) counting lexical words/content words; (3) identify clauses; (4) counting the number of clauses; (5) calculate lexical density by adopting Halliday's method [21] with the following formula.

Lexical Density $=\underline{\text { Number of Lexical Items }}$ Numbers of Ranking Clauses

\section{RESULTS AND DISCUSSION}

Data were analyzed based on Halliday's method. Thus, the order of the first study is to identify and count the lexical words contained in the controversial articles of the UU Cipta Kerja. Article 59 concerning contract workers contains:

15. Keocrtuan Pasal 59 dubah sehingga berturyà sebegai Pasal 59

(1) Perjanjan serja untuk waidu ienenta hange dape! thuat untuk peserjan tertentir lang menurut enis dan sfat atsu bexastan peckeraanmia akan seles dalam vaktu sertenth, faitu sebegai berikut

a pekejaar yang seiail selesai atau yan senentara sĭhtrits;

b. pekarjasan yarg diperkrakan perijchaiannya dilant wastu yang tidak terlalu larte

peberiagat yatg bervifar musiman;

1. pckerinan yang berbubungan dergan grodses beru, isgatan Caru, itan produk tambahy ang masih dalam procobasn atsia perigekan atera

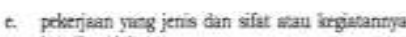
(n)

(2) Perjanjian serja untuk wekstu tertentu titak dapat diasakan untuk peloeriasn pang bersiat trtap.

(3) Pejianjian beja untuk waktu tereertu yang tiak Denenuti katentuan sebagnimang fimaksod pad arat (1) dan arat (2) deni hukmm menjedi periantian verie valnu vilak vertentu

(4) Ketentian lebih lenjut mengenai jenis dun sfaz atau kegjatan pelerjaun, janjla waltu, dan bates watu perpanjanzan perianjan keria wiktu tertentu dists dalam Perature Penerintah

SK No 050242A

Figure 1 Article 59: Contract Workers
Article 77 concerning working hours contains:

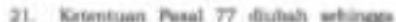

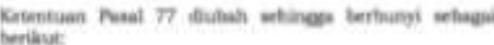

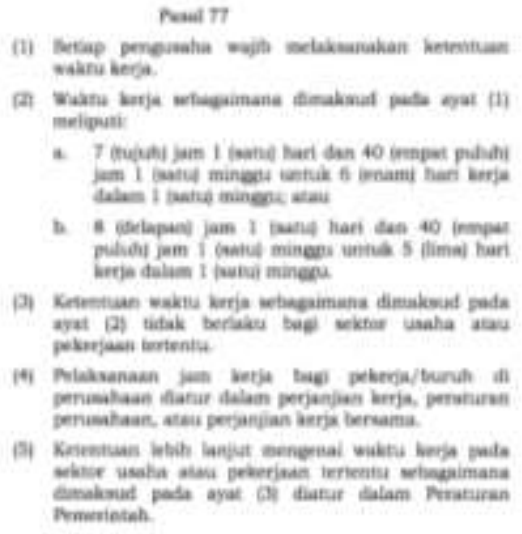

22. Eremenas.

ST nesoous A

Figure 2 Article 77: Working Hours

Article 78 concerning the overtime provisions contains:

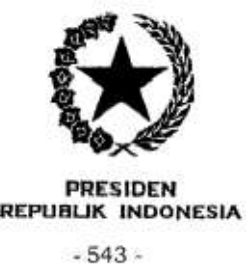

22. Ketentuan Pasal 78 diubah schingga berbunyi sebagai berikut:

Pasal 78

(1) Pengusaha yang mempekerjakan pekerja/buruh melebihi waktu kerja sebagaimana dimaksud dalam Pasal 77 ayat (2) harus memenuhi syarat:

a. ada persetujuan pekerja/buruh yang bersangkutan; dan

b. waktu kerja lembur hanya dapat dilakukan paling lama 4 (empat) jam dalam 1 (satu) hari dan 18 (delapan belas) jam dalam 1 (satu) minggu.

(2) Pengusaha yang mempekerjakan pekerja/buruh melebihi waktu kerja sebagaimana dimaksud pada ayat (1) wajib membayar upah kerja lembur.

(3) Ketentuan waktu kerja lembur sebagaimana dimaksud pada ayat (1) huruf b tidak berlaku bagi sektor usaha atau pekerjaan tertentu.

(4) Ketentuan lebih lanjut mengenai waktu kerja lembur dan upah kerja lembur diatur dalam Peraturan Pemerintah.

Figure 3 Article 78: the Overtime Provisions 
Article 79 concerning leave and rest rights contains:

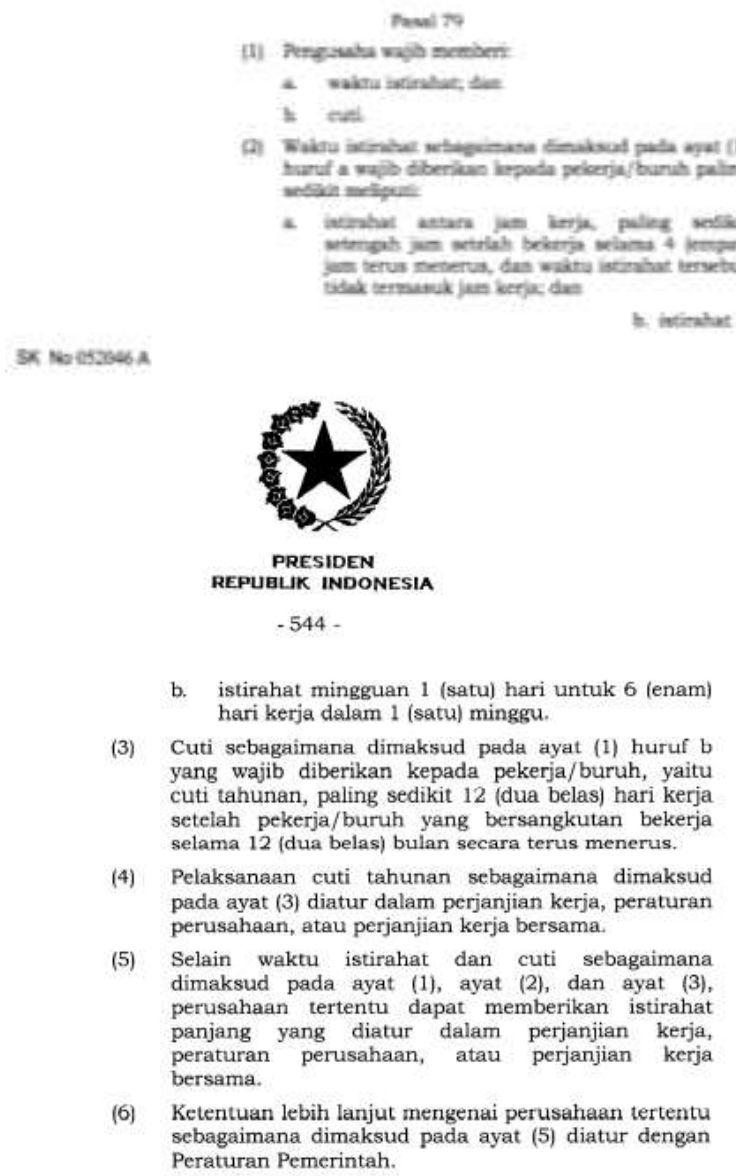

Figure 4 Article 79: Leave and Rest Rights

Based on these articles, the lexical words contained in the controversial articles of the UU Cipta Kerja are 335 words. Article 59 consists of 96 lexical words, Article 77 consists of 64 lexical words, Article 78 consists of 68 lexical words, and Article 79 consists of 107 lexical words. Lexical words in these articles are dominated by 204 nouns, followed by 75 verbs, 33 adverbs, and 23 adjectives. Analysis details are attached.

Next, the order of the study of lexical density based on Halliday's method is to identify and count the number of clauses. Amount of clauses contained in the controversial articles of the UU Cipta Kerja is 31 clauses. The details are Article 59 with 10 clauses, Article 77 with 6 clauses, Article 78 with 6 clauses, and Article 79 with 9 clauses. Analysis details are attached.

Based on the amount of lexical words and the clauses, the following is the lexical density analysis for the controversial articles of the UU Cipta Kerja.
Table 1 Lexical Density per Article of UU Cipta Kerja

\begin{tabular}{|l|c|c|c|}
\hline \multicolumn{1}{|c|}{ Article } & $\begin{array}{c}\sum \text { Lexical } \\
\text { Word }\end{array}$ & $\sum$ Clause & $\begin{array}{c}\text { Lexical } \\
\text { Density }\end{array}$ \\
\hline $\begin{array}{l}\text { Article 59 } \\
\text { concerning Contract } \\
\text { Workers }\end{array}$ & 96 & 10 & $\begin{array}{c}96 / 10= \\
9.6\end{array}$ \\
\hline $\begin{array}{l}\text { Article 77 } \\
\text { concerning Working }\end{array}$ & 64 & 6 & $\begin{array}{c}64 / 6= \\
\text { Hours }\end{array}$ \\
\hline $\begin{array}{l}\text { Article 78 } \\
\text { concerning Overtime } \\
\text { Provisions }\end{array}$ & 68 & 6 & $68 / 6=$ \\
\hline $\begin{array}{l}\text { Article 79 } \\
\text { concerning the Right } \\
\text { to Leave and Rest }\end{array}$ & 107 & 9 & 11.3 \\
\hline
\end{tabular}

Table 2 Lexical Density Controversial Articles of UU Cipta Kerja

\begin{tabular}{|c|c|c|c|}
\hline Article & $\begin{array}{c}\sum \text { Lexical } \\
\text { Word }\end{array}$ & $\sum$ Clause & $\begin{array}{c}\text { Lexical } \\
\text { Density }\end{array}$ \\
\hline Controversial articles & 335 & 31 & $\begin{array}{c}335 / 31 \\
=10.81\end{array}$ \\
\hline
\end{tabular}

Based on the analysis of the lexical density measurement using Halliday's method, it shows that Article 59 concerning Contract Workers, Article 77 concerning Working Hours, Article 78 concerning Overtime Provisions, Article 79 concerning Leave and Rest Rights contained in Chapter IV concerning Manpower of the UU Cipta Kerja has a very high lexical density index, namely 10.81 . The high lexical density index contained in these articles shows the high formality of the text. Halliday explained that the typical average lexical density can be seen from the index, depending on the formality of the text. The higher the index of a text, the more difficult the text is. The average lexical density in written text is between 3 and 6 [21].

This shows that the text is difficult to understand. High lexical density makes the text difficult to read but more informative, while low lexical density makes the text easy to read but less informative [4]. In addition, the more scientific a text, the greater the content of lexical words/content words [6]; [12]. This is relevant to the large number of lexical words contained in these articles.

The high lexical density in these articles indicates that the legal language is difficult to understand, especially by laypeople so that misunderstandings can occur in interpreting it. Therefore, simplicity of thinking and word processing skills must be possessed by legal 
product makers because if they preserve the uniqueness of legal language without considering public understanding, then the laws that have been made are only understood by legal practitioners [8]. This will make it difficult to enforce compliance and rule of law as a whole, as expressed by Hartini if community members do not understand the meaning of the formulated legal provisions, it can be assumed that the legal rules cannot be implemented. Likewise, if the law is not clearly formulated and the implementers in the field do not understand it, this will clearly have an impact on the quality of law enforcement [8].

\section{CONCLUSION}

The conclusion in this study is that article 59 concerning contract workers, article 77 concerning working hours, article 78 concerning the overtime provisions, article 79 concerning the right to leave and the rest contained in Chapter IV concerning Employment of UU Cipta Kerja has a high lexical density so that it can be categorized in scientific texts that are difficult to read, especially for the laypeople.

Therefore, it is necessary to simplify the legal language to increase its readers' understanding and realize legal compliance and order. One of the efforts that can be made to increase the reader's understanding of legal texts is to reduce the level of lexical density of legal language so that the laws made are more effective, especially in public comprehension.

\section{REFERENCES}

[1] Ahmad, Nur Aina. 2017. Problematika Penggunaan Bahasa Hukum Indonesia. Jurnal Al-Himayah, (1) 145-157.

[2] Bivins, Peggy. 2008. Implementing Plain Language Into Legal Documents: The Technical Communicator's Role. Stars: 1-187.

[3] Eggins, S. 2004. An Introduction to Functional Linguistics. London: Continuum Internasional Publishing Group.

[4] Halliday, M A K. 2005. Some Grammatical Problems in Scientific English in M.A.K. Halliday and J.R. Martin 1993. Writing Science: Literacy and Discursive Power. London: The Falmer Press.

[5] Halliday, M.A.K. 2004. An Introduction to Functional Grammar (Third Edition). London: Arnold.

[6] Halliday, M.A.K. 1998. Things and Relations: Regrammaticalising Experience as Technical Knowledge. Reading Science: Critical and
Functional Perspective on The Discourse of Science (Routledge), 185-236.

[7] Harkristuti, Harkrisnowo. 2003. Bahasa Indonesia sebagai Sarana Pengembangan Hukum Nasional. Kongres Bahasa Indonesia VIII. Jakarta: Pusat Bahasa.

[8] Hartini, Lilis. 2019. Bahasa dan Produk Hukum. Bandung: Refika Aditama.

[9] Johansson, Victoria. 2008. Lexical Diversity and Lexical Density in Speech and Writing: A Developmental Perspective. Working Press, 53: 61-79.

[10] John, A. 2017. Pathlegal Website. 31 Mei. Diakses April 13, 2021. https://www.pathlegal.in/Why-islegal-language-so-complicated--blog-1048999.

[11] Mahadi, dan Ahmad Sabaruddin. 1979. Penggunaan Bahasa Hukum Indonesia. Jakarta: Bina Cipta.

[12] Maton, Karl, dan Yaegan Doran. 2017. Semantic Density: A Translation Device for Revealing Complexity of Knowledge Practices in Discourse, Part 1-Wording. Onomazein, 1: 46-76.

[13] Mufidah, Z, dan D Wenanda. 2017. Kepadatan Leksikal Buku Ajar Muatan Lokal Bahasa Madura untuk Kelas VI Sekolah Dasar. Prosodi, 11 (2): 109-118.

[14] Mukherjee, Namrata dkk. 2017. Manual on Plain Language Drafting. Vidhi: Centre for Legal Policy: $1-57$.

[15] Putra, D A, dan Iwa Lukmana. 2017. Text Complexity in Senior High School English Textbooks: A Systemic Functional Perspective. IJAL, 7 (2): 436-444.

[16] Ramadhan, M R. 2017. Lexical Density and Grammatical Intricacy in Written and Spoken Texts. Accessed on November 29, 2020. Available in

http://repositori.usu.ac.id/handle/123456789/5866.

[17] Susette. 2020. Writer Access Website. 4 September. Accessed on April 13, 2021. Available in https://www.writeraccess.com/blog/simplifyinglegal-writing/.

[18] Syarif, Hermawati. 2018. Lexical Density V.S. Grammatical Intricacy: How Are They Related? ICOELT: Advances in Social Science, Education and Humanities Research, 16-22. 
[19] Tempo.co. 2020. 6 Oktober. Diakses November 28, 2020.https://nasional.tempo.co/read/1393292/nasib -empat-pasal-kontroversial-dalam-uu-cipta-kerja.

[20] Thornbury, S. \& Slade, D. 2006. Conversation: From Description to Pedagogy. Cambridge UK: Cambridge University Press.

[21] To, Vinh., et.al. 2013. Lexical Density and Readability: A Case Study of English Textbooks. Internet Journal of Language, Culture, and Society, (37): 61-71.

[22] Williams, Christopher. 2015. Changing with the Times: The Evolution of Plain Language in the Legal Sphere. Alicante Journal of English Studies, (28): 183-203.

[23] Williams, Christopher. 2004. Legal English and Plain Language: an Introduction. ESP Across Cultures, 1: 111-124.

[24] Wiratno, Tri. 2018. Pengantar Ringkas Linguistik Sistemik Fungsional. Yogyakarta: Pustaka Pelajar 